\title{
ARBORES FRUTICESQUE CHINENSES NOVI. III ${ }^{\mathrm{I}}$
}

Camillo SCHNEIDER

Cotoneaster (Sect. Chaenopetalum Koeh.) oligocarpa, n.sp.Frutex latus, erectus, ad $4 \mathrm{~m}$. altus; ramuli hornotini initio tomento villosulo flavescenti-cinereo adpresso obtecti, annotini satis glabrescentes, fusco-rubri, vetustiores glabri, plus minusve cinerascentes. Folia subcoriacea, partim persistentia, ovalia, obovatoelliptica vel praesertim versus apicem ramulorum ovata (in specimine florenti distinctius obovata), apice acuta et mucronulata vel satis obtusa et interdum subrotundata, basi pleraque late cuneata, $2 \cdot 5-5 \mathrm{~cm}$. longa et $\mathbf{I} \cdot 2-2 \cdot 5 \mathrm{~cm}$. lata, superne saturate, sed ut videtur obscure, viridia, initio laxe villosula, biennia costa impressa excepta glabra, subtus modo ramulorum novellorum dense tomentosa, etiam adulta haud vel tantum in costa elevata paullo glabrescentia, in facie sub microscopio papillis distinctis non praedita, nervis lateralibus superne plus minusve impressis subtus satis prominentibus utrinsecus 8-12; petioli dense tomentosi, vix ultra $6 \mathrm{~mm}$. longi; stipulae triangulari-lanceolatae, acuminatae, petiolis breviores, subtus dense tomentosae, superne glabriores. Corymbus satis densus, multiflorus, ad $4 \mathrm{~cm}$. (vel ultra?) latus et ad $3.5 \mathrm{~cm}$. altus, villosus, bracteis bracteolisque deciduis subulatis circ. $3 \mathrm{~mm}$. longis; pedicelli $\mathrm{I}-3 \mathrm{~mm}$. longi, ut pedunculi villosi; flores albi; receptaculum ovato-turbinatum ut sepala late triangularia circ. $\mathrm{I}-\mathrm{I} .5 \mathrm{~mm}$. longa apice glanduloso-mucronulata intus glabra satis dense tomentosulum, ad $2.5 \mathrm{~mm}$. longum;

I Through an unfortunate coincidence, three of the species of Mahonia proposed by me in the previous paper (Bor. GAz. 63: $519^{-121}$. I 197 ) have been described by TAKEDA in his "Contributions to the knowledge of the Old World species of the genus Mahonia" (Not. Roy. Bot. Gard. Edinburgh, nos. 29, 30, January 19r7). I had no knowledge of this publication until it was too late to change the names in my paper.

$M$, caesia Schn. is apparently the same as $M$. bracteolata Takeda, of which I have not yet seen the type or the figure, TAKEDA's being not yet published. $M$. nivea Schn. becomes a synonym of $M$. hypoleuca Takeda; and TAKEDA is the first author of $M$. philippinensis. Henry's no. I0309, cited by me under M. Alexandri Schn., is referred by TAKEDA to his new $M$. lomariifolia, of which I have cotypes before me. I do not believe that the two species are the same, the shape and color of the leaflets being, in my opinion, too different. 
petala orbicularia, circ. $2.5 \mathrm{~mm}$. lata, basi unguiculata, intus pilosula; stamina 2o, petalis paullo breviora, antheris ut videtur violaceis; carpidia 2 , apice sparse villosa, stylis quam stamina fere longioribus stigmatibus capitatis planis. Fructus parvi, rubri, subglabri vel satis villosuli, plus minusve turbinati, 4-5 $\mathrm{mm}$. longi, apice circ. $3 \mathrm{~mm}$. crassi, sepalis extus villosulis incumbentibus fere clausi; pyrenia 2, obcordato-ovoidea, circ. $3.5 \mathrm{~mm}$. longa et infra medium $2 \cdot 5^{-3} \mathrm{~mm}$. lata, stylum in apice vel paullo infra gerentia, ventre leviter carinata, subnitentia, dorso paullo sulcata, basi hypostylii leviter constricta, hypostylio circ. trientem dorsi occupante villosulo.

Yunnan boreali-occidentalis: in dumetis ad vias inter Ho-ching et Lichiang-fu, alt. circ. 2600 m., 25 Septembris I9I4, C. Schneider (no. 3070; typus in Herb. Arb. Arn. et Hb. Schneider).-Szechuan australis: ad vias in declivibus montium prope Wo-lo-ho, alt. circ. $2800 \mathrm{~m}$., I3 Junii I9I4, C. Schneider (no. I498; foliis pro parte distinctius obovatis).

Judging by its very small fruits, this species is closely related to $C$. salicifolia Fr. which, however, may easily be distinguished by its more lanceolate and more acuminate leaves, which are more deeply furrowed and rugulose above and more glabrescent on the strongly prominent midrib and veins beneath, by its almost glabrescent fruiting inflorescences, and by the glabrous larger hypostyle. C. salicifolia var. rugosa R. and W. and var. floccosa R. and W. differ by the same characters of the leaves and by their larger more subglobose fruits. Its nearest relative may be $C$. Harrowiana Wils., of which I have not yet seen the fruit; but the old leaves of this species are much more glabrescent beneath. Having introduced $C$. oligocarpa into cultivation, it has to be decided by observation of living plants whether it is a good species or only a variety of $C$. Harrowiana which comes from southern Yunnan. C. salicifolia and its varieties, C. Harrowiana and C. oligocarpa, certainly form a group of very closely related species which may be distinguished from $C$. Henryana $\mathrm{R}$. and $\mathrm{W}$. and its allies by their leaves bearing no distinct papillae on the under surface, while on the leaves of $C$. Henryana the papillae are very distinct under the microscope.

Cotoneaster (Sect. Chaenopetalum Koeh.) Vernae, n.sp.Frutex erectus, elongato-ramosus, altitudine incerto; ramuli hornotini dense cinereo- vel subflavescenti-villosulo-tomentelli, annotini plus minusve glabrescentes, fusco-rubri. Folia partim persistentia, subcoriacea, elliptico-oblonga, apice obtusa vel rotundata, basi acute vel obtuse cuneata, $2-3.5 \mathrm{~cm}$. longa, 0.8I. $5 \mathrm{~cm}$. lata, superne saturate viridia, subnitentia, etiam novella 
tantum in costa impressa pilosa, facie plana sed tenuissime reticulata nervis non incisis, subtus dense ut ramuli tomentosa, etiam biennia tantum in costa prominente paullo glabrescentia, nervis lateralibus utrinsecus $5-7$ vix vel paullo prominulis; petioli vix ad $5 \mathrm{~mm}$. longi, dense tomentelli; stipulae anguste triangulari-lanceolatae, acuminatae, petiolis breviores, subglabriores. Corymbus pluriflorus, ad $3 \mathrm{~cm}$. latus et $2.5 \mathrm{~cm}$. longus, dense villoso-tomentosus; pedicelli $\mathrm{I}-2 \mathrm{~mm}$. longi, ut pedunculi tomentelli, bracteis bracteolisque deciduis; flores ignoti; fructus parvi, obscure rubri, turbinati vel globoso-turbinati, circ. $4 \mathrm{~mm}$. longi et $3 \mathrm{~mm}$. crassi, plus minusve villosuli, apice sepalis incumbentibus extus villosis fere clausi; pyrenia 2, circ. $3 \mathrm{~mm}$. longa et $2.5 \mathrm{~mm}$. lata, obovoidea, ventre plana, satis laevia, nitidula, dorso leviter rugulosa, stylum apice gerentia, hypostylio circ. trientem dorsi occupante villosulo.

Yunnan boreali-occidentalis: ad latera orientalia montium niveorum prope Lichiang-fu, alt. circ. $3000-3200 \mathrm{~m}$., Octobri I914, C. Schneider (no. 2676; typus in Herb. Arb. Arn. et Hb. Schneider).

The fruits of this species are extremely like those of $C$. oligocarpa Schn., previously described, but in its narrow elliptic obtuse leaves, which are smooth above and show very little prominent veins beneath, $C$. Vernae differs widely from all the species mentioned above. It seems to be more closely related to C. pannosa Fr. which, however, can easily be distinguished by its more ovate acute or shortly acuminate leaves, and by its larger fruits, the sepals of which are more erect. I am unable to identify my no. 2676 with any Chinese species hitherto described. I introduced it into cultivation (seed no. 578 ), and observations of living plants may give further indications of the real relationship of this apparently well marked species. It is named for my daughter Verna.

Prunus LATIdentata Koeh., var. trichostoma, n.var.P. trichostoma Koehne in Sargent, Pl. Wils. I: 2 I6. I912.-A typo non nisi sepalis intus et stylis basi distinctius pilosis differre videtur.

Szechuan australis: in regione Yen-yüan Hsien, inter viculos Ka-la-pa et Liu-ku, in sepibus, alt. circ. $3200 \mathrm{~m}$., I 7 Maji I9I4, C. Schneider (no. I 2 Io; frutex ad $2 \mathrm{~m}$. altus); inter viculos Hun-ka et Wo-lo-ho, alt. circ. $3300 \mathrm{~m}$., I3. Junii I9I4, C. Schneider (no. 3520; arbuscula vel arbor ad $6 \mathrm{~m}$. alta).

According to KOEHNE's own statement, there is really no other difference between $P$. latidentata and $P$. trichostoma than the pubescence inside the sepals. So far as I can judge by the specimens before me, this character seems to be not sufficient to separate these two species. In my specimens the branchlets and pedicels are a little more hairy, and it seems to me rather difficult to decide to which of KOEHNE's types the two numbers of mine are to be referred. 
POTENTILla ERIOCARPA Wall., var. cathayana, var. nov.? P. eriocarpa Franchet, Pl. Delav. 21 . I889, non Wall., sensu Lehmann et Wolf; Diels in Not. Bot. Gard. Edinbgh. 7: I57. I9I 2, 387. I9I3.-A typo a cl. Lehmanno depicto recedit foliolis omnibus sessilibus, inflorescentiis ad 3 -floris, sepalis externis ovatolanceolatis subacuminatis quam interna paullo latiora saepe distinctius acuminata vix vel paullo brevioribus.

Yunnan boreali-occidentalis: in fauce infra glaciem parvam montium niveorum prope Lichiang-fu, in rupestribus calcareis, alt. circ. $3900 \mathrm{~m}$., I7 Augustii $\mathrm{I}_{914}$, C. Schneider (no. 2274; typus in Herb. Arn. Arb. et Hb. Schneider; suffrutex floribus magnis luteis, ramulis floriferis $5-15 \mathrm{~cm}$. altis).

According to the figure given by LEHMANN and to WoLF's description, the typical $P$. eriocarpa Wall. has "sepala externa late elliptica obtusa vel rotundata," and the leaflets are described as "plus minusve longe petiolulata (saltem terminale):" The petals of var. cathayana seem also to be much more emarginate than those of the type.

Rubus (Subgen. IdaEobatus Focke, sect. IDAEANTHI Focke) testaceus, n.sp.-Frutex habitu R. Idaei ad I. 5 m. altus, dumeta formans; rami vetustiores teretes, aculeis paucis aculeolis sparsis vel crebris rectis armati, satis dense villosuli et glanduloso-setulosi, setulis intermixtis, partim glabrescentes et testacei; ramuli floriferi ut videtur nondum satis evoluti ad ro $\mathrm{cm}$. longi, cum petiolis pedicellisque densius griseo-villosuli et etiam glanduliferi et parce setulosi. Folia visa omnia ternata; foliola ovato-rhomboidea vel rhomboideo-orbicularia, is $R$. schizostyli ex icone a cl. Focke in monogr. p. 206 dato satis similia, terminalia petiolo ad $\mathrm{I} \mathrm{cm}$. longo suffulta, maxima visa ad $3 \cdot 5 \mathrm{~cm}$. longa et $3 \mathrm{~cm}$. lata, apice rotundata, obtusa (vel rarius in foliolis satis juvenilibus oblongioribus subacuta), lateralia subsessilia, ad I. $8 \mathrm{~cm}$. longa et $\mathrm{I} .5 \mathrm{~cm}$. lata, omnia subaequaliter satis grosse dentata vel inaequaliter dentatoserrata, sublobulata, superne satis flavo-viridia, laxe vel initio densius subadpresse hirto-pilosa et glandulosa, subtus vix discoloria, facie glabriuscula, in costa nervisque lateralibus utrinsecus (3-) $4(-5)$ hirta et plus minusve glandulosa; petioli ad $2 \mathrm{~cm}$. longi; stipulae lineares ad $6 \mathrm{~mm}$. longae, praesertim extus villosae et glanduliferae. Flores axillis foliorum ex parte quasi ad bracteas reductorum singuli, apice ramulorum floriferorum pseudoracemas ad 6-(vel pluri-?) floras formantes, rubri, iis $R$. triphylli similes, circ. $\mathrm{I} .5 \mathrm{~cm}$. diametientes; pedicelli ad $\mathrm{I}_{5} \mathrm{~mm}$. longi, medio saepe 
bractea stipulis simillima instructi; calyx externe modo pedicellorum villosulus, glanduliferus et parcissime setulosus, sepalis lanceolatis acuminatis margine albo-villosis circ. $7 \mathrm{~mm}$. longis patentibus intus basi glabrioribus; petala oblonga vel satis anguste obovatooblonga, versus apicem acutiusculam undulato-marginata, basim versus longe cuneata, intus sparse pilosa, demum ut videtur patentia, sepalis subaequilonga et ultra medium circ. $3-3 \cdot 5 \mathrm{~cm}$. lata; stamina in flore ut videtur erecto-patentia, circ. 70-75, filamentis glabris longioribus petalis subaequilongis; carpophorum pilosum; carpidia circ. $30,4 \cdot 5-5 \mathrm{~mm}$. longa, stylis glabris, ovariis ima basi pilosis et dorso pilis parcis praeditis; discus glaber. Fructus ignoti.

Szechuan australis: in regione Yen-yüan Hsien, inter viculos Ka-la-pa et Liu-ku, alt. circ. 3500 m., I7 Maji I9I4, C. Schneider (no. I 269; frutex ad r. $4 \mathrm{~m}$. altus, dumeta formans, foliis valde juvenilibus); eodem regione, ad viam inter Liu-ku et Kua-pie, alt. circ. $2800 \mathrm{~m}$., I9 Maji I9I4, C. Schneider (no. I213; flores rubri).-Yunnan boreali-occidentalis: in regione Yung-ning, versus pagum Mu-ti-chin, alt. circ. $2800 \mathrm{~m} ., 23$ Junii 1914, C. Schneider (no. 3894 ; typus in Herb. Arb. Arn. et Hb. Schneider).

Judging by the shape of the leaves, this species seems to be very similar to $R$. schizostylus Lév., which I know only from the figure given by FockE in his Mon. Gen. Rubi Prodr. in Bibl. Bot. 72: 206. fig. 83. I9I1; but according to the description of the author this Corean species differs widely in having "rami rubescentes glabri ... foliola . . . subtus cinerea . . . p pilis adpressis albis." R. mesogaeus Focke, 1.c. 204. fig. 82, which is found in Hupeh and Szechuan, has white or pink flowers, and is otherwise extremely different. Another species to which $R$. testaceus may be related is $R$. kanayamensis Lév. and Van. in Bull. Soc. Bot. France 53: 549. 1906 et apud Focke, 1.c. 205, from Japan, of which the leaves are described as "in utraque pagina viridia et parce pilosa," but it has an "inflorescentia laxe effusa," and, according to FockE's statement, "revocat $R$. id. subspec. strigosum," the shape of the leaves of which is entirely different: The specific name of the new species refers to the pale brick red color of the older glabrescent branches.

Rosa MAIREr Lév., var. plurijuga, n.var.-A typo praecipue recedit foliis $5^{-6}$-jugis, foliolis etiam superne plus minusve dense villosulis.-Fructus plantae typicae incogniti, in varietate magni, rubri, ad $15 \mathrm{~mm}$. crassi et $18 \mathrm{~mm}$. longi (sepalis persistentibus exclusis), obovato-globosi, praesertim ad apicem tomentelli, ceterum glabri, basi subsensim in pedicellum contracti, apice sepalis utrinque dense villosulo-tomentellis lanceolato-triangularibus acuminatis]ad $15 \mathrm{~mm}$. longis basi circiter $6 \mathrm{~mm}$. latis coronati, 
pedicelli ad $18 \mathrm{~mm}$. longi, plus minusve tomentelli, apice excepto non incrassati.

Yunnan boreali-occidentalis: in declivibus herbosis calcareis montium Tsang prope Tali-fu, alt. circ. $2800 \mathrm{~m}$., Augusto 1914, C. Schneider (no. 2526; typus in Herb. Arb. Arn. et Hb. Schneider).

This variety agrees well with typical $R$. Mairei Lév. except that the leaves have $5^{-6}$ pairs of leaflets instead of only $2-4$ pairs. Unfortunately the fruits of the type are still unknown. ReHDER and Wilson in Sargent, Pl. Wils. 2: 344 . I9I5, say that $R$. Mairei "is probably nothing more than a very hairy and small-leaved variety of $R$. omeiensis Rolfe." In my opinion, it seems much more closely related to $R$. sericea Ldl. which, however, comes very near $R$. omeiensis. The new variety may be identical with the true $R$. sericea, f. pteracantha Franchet in Pl. Del. 220. $1889=R$. sericea Crépin in Bull. Soc. Roy. Bot. Belg. 25: 9. I886, ex parte, quoad no. 86 I Delavayi, which he describes as having "folia majuscula utraque facie sericeo-tomentella," but he does not mention the number of the leaflets neither does CRÉPIN. FRANChet's f. pteracantha, however, is not identical with $R$. sericea var. pteracantha in Gard. Chron. III. 28: 260. figs. 98, 99, 1905; and in Bot. Mag. 134: $p l$. 8218 . 1908, which is the same as $R$. omeiensis f. pteracantha R. and W. in Sarg., Pl. Wils. 2: 332. I915.

The typical $R$. omeiensis Rolfe is well characterized by its $9-13$-foliolate leaves, the leaflets of which are entirely glabrous or hairy only on the midrib beneath, and by the distinctly thickened and colored (yellow or red) footstalks of the ripe fruits (see Bot. Mag. 138: pl. 847I. 1912); but there are certain hairy forms with almost subsessile fruits and fewer leaflets which come very near to $R$. Mairei as well as to $R$. sericea. The type of $R$. sericea as represented by LiNdLey in his Rosac. Monogr. 105. pl. I2. 1820, has $7^{-11}$ leaflets which are "green and naked above, paler, with the rib and the principal veins silky beneath." We certainly need a careful study of all the forms of these 3 species which, after all, seem to be so closely connected by intermediate forms that they may have to be united under $R$. sericea which we have to study as CRÉPIN said, "au point de vue des variations que peut éprouver un type dans le revêtement de ses axes et de ses feuilles." By WiLson, Forrest, and myself many forms have been introduced into cultivation, so that we shall be able to judge the value of the different characters presented by the leaves, fruits, and branchlets by the behavior of living plants.

Rosa (Sect. Cinnamomeae DC.) atroglandulosa, n. sp.Frutex latus erectus, ad I. $5 \mathrm{~m}$. altus; rami purpurascentes glabri, aculeis satis sparsis vel in ramulis floriferis tantum infrastipularibus rectis acicularibus basi subito plus minusve dilatatis ad 8-9 mm. longis flavis muniti; turiones non visi. Folia satis crassa, chartacea, 5 -foliolata, petiolo incluso $5-8 \mathrm{~cm}$. longa; foliola breviter petiolulata, ovalia, ovato-elliptica, rarius obovalia, apice satis obtusa 
vel breviter acuta, basi plus minusve rotundata, rarius late cuneata, lateralia inferiora minora ( $\left.\mathrm{I}_{3}^{-}\right) \mathrm{I}_{5}^{-22} \mathrm{~mm}$. longa, (8-) I0- $15 \mathrm{~mm}$. lata, superiora majora ad $3.2 \mathrm{~cm}$. magna, terminalia superioribus plus minusve aequalia sed saepe paullo latiora, margine dupliciter inaequaliter glanduloso-serrata (sublobulata) dentibus majoribus mucronulatis porrectis dorso denticulas I- 3 gerentibus, superne viridia, in sicco leviter glaucescentia, laevia, glabra (interdum sparsissime glanduloso-pilosa), subtus viridescentia, dicoloria, in costa et etiam partim in nervis lateralibus utrinsecus $5^{-8}$ paullo prominulis satis rectis plus minusve pilosa et etiam ut in facie pilis glanduliferis crebris conspersa (oculo nudo quasi nigropunctata), rete nervillorum subvisibili; petioli $2-3.5 \mathrm{~cm}$. longi, ut rhachis plus minusve dense villosuli, stipitato-glandulosi et setis aculeolisque sparsis muniti; stipulae satis evolutae, ad medium adnatae, I0-13 $\mathrm{mm}$. longae, auriculis latis acuminatis, margine dense glanduloso-ciliatae, ceterum ut folia pilosa et glandulifera. Flores kermesini, suaveolentes, circ. $3 \mathrm{~cm}$. diametientes, solitarii vel 2-3 apice ramulorum ad $8 \mathrm{~cm}$. longorum terminales; pedicelli IO-I $2 \mathrm{~mm}$. longi, basi bracteis ovatis vel late ovatis apice subito acuminatis ad $12 \mathrm{~mm}$. longis et 8-9 $\mathrm{mm}$. latis dense glandulosociliatis suffulti, glabri, interdum fere nudi sed plerique crebre stipitato-glandulosi; receptaculum ellipsoideo-oblongum, glabrum, nudum; sepala ovato-oblonga, extus glabra vel interiora versus marginem tomentella, intus tomentosula, eglandulosa, post florationem reflexa; alabastra ovata, obtusa; petala late obovata, emarginata, ad $2 \mathrm{~cm}$. longa et $1.7 \mathrm{~cm}$. lata; stamina numerosa, antheris luteis ovalibus; styli liberi, circ. $5 \mathrm{~mm}$. exserti, staminibus longioribus vix breviores, villosi. Fructus ignoti.

Szechuan australis: inter urbem Yen-yüan Hsien et viculum Hun-ka, ad vias, alt. circ. $2600-2800 \mathrm{~m}$., II Junii 1914, C. Schneider (no. 1484; typus in Herb. Arb. Arn. et Hb. Schneider).

This species seems to me most closely related to $R$. Sweginzowii Koehne (see figure in Fedde, Rep. Spec. Ir: 531. fig. 3) and R. setipoda Hemsl. and Wils. (see Bot. Mag. 140: pl. 8569), which may easily be distinguished in having $7^{-9}$ leaflets and a different kind of wide-based prickles. $R$. atroglandulosa seems to be well marked by the frequent stipitate dark glands on the under surface of the leaves and the rather long exerted styles. I cannot refer it, even as a variety, to any of the species of this section enumerated by A. REHDER in Sarg., Pl. Wils. 2: 339 . 1915. 
Rosa Soulieana Crép. var. yunnanensis, var. nov.- $R$. moschata var. yunnanensis Focke in Not. Bot. Gard. Edinbgh. 5:69. I9II, nom. nud., non Crépin apud Franchet; Diels, l.c. 7:I24. I9I 2 et 394. I9I3, nom. nud.; $R$. Soulieana R. and W. in Sarg., Pl. Wils. 2:314. I915, quoad synon. Fockii et specim. Forrestii, non Crépin.-A typo recedit rhachi foliorum et costa foliolorum subtus puberula, pedicellis receptaculisque minute flavo-glanduloso-pilosis et etiam interdum pilosulis.

Szechuan australis: inter viculos Wo-lo-ho et $\mathrm{Hu}$-ma-ti ad viam versus Yung-ning, alt. circ. $2800 \mathrm{~m}$., I4 Junii I9I4, C. Schneider (no. I549; frutex ad $2.5 \mathrm{~m}$. altus, patenter dense ramosus, floribus albis odoratis).

The main difference between the type and this variety seems to be the fine pubescence of the rhachis and of the midrib of the under side of the leaflets, which is not always present on the pedicels and receptacles. These are more or less covered with a short, yellowish, glandular pubescence which I find also on a cultivated specimen from VILMORIN's fruticetum, Les Barres. VILMORIN's plant, probably, came from the type plant in the Jardin des Plantes in Paris. The shape of the leaflets, which are described by Franchet as "courtes, ovales et plus ou moins arrondies, à base arrondie, obtuses- arrondies au sommet, plus rarement très brusquement mucronées," varies to a certain degree, and especially the leaves of ForREsT's no. 2370 from Lichiang, which is the type of var. yunnanensis of Focke, are rather acute at both ends.

VIBURNUM CYLINDRICUM Ham., var. crassifolium, n. var.Viburnum crassifolium Rehder in Sarg., Pl. Wils. 2:112. I913.A typo cum varietate ut videtur formis intermediis conjuncto differt praecipue inflorescentiis plus minusve vel satis dense pubescentibus.

Szechuan australis: in regione Yen-yüan Hsien versus occidentem inter viculos Hu-ma-ti et Wo-lo-ho, alt. circ. 2800-3000 m., I4 Junii r9r4, C. Schnei$\operatorname{der}$ (no. $155^{2}$; arbuscula vel arbor ad 6:0.4 m.). -Yunnan boreali-occidentalis: in dumetis inter viculos Pi-ji et Pao-to versus Yung-ning, alt. circ. $2400 \mathrm{~m}$., 25 Junii $191_{4}, C$. Schneider (no. 3508; frutex ad $3 \mathrm{~m}$. altus); in dumetis ad pedem orientalem montium niveorum prope Lichiang-fu, alt. 2900-3200 m., 29 Julii r9r4, C. Schneider (no. 2034; frutex 2-3 metralis); eodem loco, Octobri r9r4, C. Schneider (no. 3212).

Regarding the size of the leaves and the sparser pubescence of the inflorescences, these specimens are intermediate between the type of $V$.crassifolium Rehd., collected by A. HeNRY in southern Yunnan near Mengtsze (no. 9797), and the typical $V$.cylindricum Ham. to which I refer the following numbers of my own collections: Szechuan australis: in regione Yen-yüan Hsien, in silvis prope Liu-ku, alt. 3000 m., I9 Maji 1914 (no. I315; frutex ad 2 metralis); 
prope Kua pie, alt. circ. 3000 m., 2I Maji I9I4, (no. I345; frutex vel arbor, 3-6 metralis); in regione Hua-li, in dumetis declivium ad flum. Yalung, alt. 2300 m., 30 Maji I9r4 (no. 1395).

VIBURNUM CALVUM Rehd., var. puberulum, n. var.-A typo praecipue recedit: ramulis hornotinis et saepe annotinis biennesque et etiam inflorescentiis plus minusve puberulis.-Fructus atrocyanei, nitiduli, ovato-globosi, circ. $5 \mathrm{~mm}$. longi et $4 \mathrm{~mm}$. crassi, iis $V$. propinqui similes sed minus distincte apiculati; semina ovoideo-globosa, ventre leviter sulcata, albumine ruminato.

Szechuan australis: inter Hoh-si et Yen-yüan Hsien prope pagum Loma-pu, in dumetis montium, alt. circ. $2200 \mathrm{~m}$., 9 Maji 1914, C. Schneider (no. Ir46; frutex virgultus, I. $5^{-2} \mathrm{~m}$. altus, floribus albis, fructibus atrocyaneis); in regione Kua-pie, in declivibus dumosis calcareis montium, alt. circ. $3000 \mathrm{~m}$. 20 Maji I914, C. Schneider (no. I325; typus in Herb. Arn. Arb. et Herb. Schneider; frutex sempervirens, I-I.5 m. altus, fructibus nitidis nigris).

According to the shape and the nervation of the leaves, and to the size of the inflorescence, this form is very similar to the typical $V$. calvum Rehd. from southern Yunnan, of which the fruits are not yet known. The fruits I collected are about the same as those of $V$. propinquum Hemsl. which, however, can easily be distinguished by its 3 -nerved leaves.

There is another very interesting species I found in Yunnan boreali-occidentalis: inter Hoching et Teng-chuan, in silvis apertis prope Sung-queh versus angustias montium, alt. circ. $3200 \mathrm{~m}$., 29 Sept. I9I4 (no. 2873 ; frutex 3 -metralis). The shape of the ovate-oblong or oblong-elliptic leaves, which measure up to $8 \mathrm{~cm}$. in length and $2.8 \mathrm{~cm}$. in width, is similar to those of $V$. propinquum, but they are not distinctly acuminate and not 3 -nerved at the base, but have the same nervation as $V$. calvum. The fruiting corymbs are small, and bear only a few fruits, which, unfortunately, are not yet fully ripe. They are almost globose, and about $5 \mathrm{~mm}$. in diameter. I cannot refer this form to any species hitherto described from China, but $I$ believe it is very near or the same as $V$. atrocyanea (sic!) C. B. Clarke apud Hook. and Thom., Fl. Brit. Ind. 3:7. I880 from the Mishmi Mountains in Bhutan, which I know only from the rather insufficient description of the author. 


\section{$2 \mathrm{BHL}$ Biodiversity Heritage Library}

Schneider, Camillo. 1917. "Arbores Fruticesque Chinenses Novi. III." Botanical gazette 64(1), 70-78. https://doi.org/10.1086/332086.

View This Item Online: https://www.biodiversitylibrary.org/item/109348

DOI: https://doi.org/10.1086/332086

Permalink: https://www.biodiversitylibrary.org/partpdf/223898

\section{Holding Institution}

Missouri Botanical Garden, Peter H. Raven Library

\section{Sponsored by}

Missouri Botanical Garden

\section{Copyright \& Reuse}

Copyright Status: Public domain. The BHL considers that this work is no longer under copyright protection.

This document was created from content at the Biodiversity Heritage Library, the world's largest open access digital library for biodiversity literature and archives. Visit BHL at https://www.biodiversitylibrary.org. 